\title{
Serum Antistaphylococcal Alpha-haemolysin Titres in Cystic Fibrosis*
}

\author{
VICTOR F. IACOCCA and GIULIO J. BARBERO $†$ \\ From The Children's Hospital of Philadelphia, Department of Pediatrics, School of Medicine, \\ University of Pennsylvania
}

The presence of coagulase-positive staphylococci in the pulmonary tract of patients with cystic fibrosis (CF) has been well established (Huang, Van Loon, and Sheng, 1961; Iacocca, Sibinga, and Barbero, 1963).

Investigators (Halbert, di Sant' Agnese, and Kotek, 1960; Gladstone et al., 1962; Mudd et al., 1962; Quie and Wannamaker, 1964) have demonstrated serum antibodies to the microbial organisms commonly found in the tracheobronchial secretions of CF patients. This is a study of the anti- $\alpha-$ haemolysin (AAH) response in patients with $\mathrm{CF}$ to the chronic staphylococcal infection of t':eir lungs.

\section{Material and Methods}

The sera of 138 patients with cystic fibrosis who had staphylococcal organisms in the respiratory tract were assayed for AAH. All patients with CF were clear cases with pulmonary and gastro-intestinal involvement coupled with chest and sinus $x$-ray changes, raised sweat electrolyte concentrations, and almost complete pancreatic achylia. The patients were categorized into mild or severe groups. The mild category consisted of patients with good nutrition, only occasional respiratory illness, and no evidence of chronic respiratory disease. All other degrees of respiratory involvement and growth failure were included in the severe group in this study. When a patient in the mild or severe group had clinical evidence of a respiratory exacerbation followed by a return to his initial state, he was placed categorically into a mild or severe 'with exacerbation' group. The samples of sera which served as control material came from the following sources: (1) 70 sera from patients with gastro-intestinal symptoms, such as chronic constipation and recurrent abdominal pain; (2) 32 sera from patients in an allergy clinic with recurrent asthma; (3) 21 sera from children with an acute respiratory disease, such as tracheobronchitis, bronchopneumonia,

Received May 30, 1967.

* This study was supported by a grant from United States Public Health Service and by the National Cystic Fibrosis Research Foundation.

† Present address: Hahnemann Medical College and Hospital, 230 N. Broad Street, Philadelphia, Pa, 19102, U.S.A. and lobar pneumonia; 9 of these patients had acute staphylococcal respiratory infection considered as staphylococcal pneumonia; (4) 12 sera from children with rheumatic fever; and (5) 24 sera from patients with various other non-infectious illnesses.

Standard staphylococcus anti- $a$-toxin ${ }^{\star}$, containing 20 International Units per ml., was diluted for testing to contain 1 unit $/ \mathrm{ml}$.

A freeze-dried preparation of staphylococcus ahaemolysin, whose haemolytic activity is expressed in terms of equivalents of International Units of staphylococcus AAH $\dagger$, was standardized for each serological test against the standard antitoxin and diluted to contain 0.5 unit equivalent $/ \mathrm{ml}$.

Rabbit blood was collected by cardiac puncture, heparinized, and added to an equal volume of sterile Alsever's solution. These erythrocytes were stored at $2-5^{\circ} \mathrm{C}$. for up to one week while being used. On the day of titration, a portion of these cells was washed three times with the diluent (normal saline containing $0.1 \%$ gelatin) and diluted to make a $2 \%$ suspension.

All sera were collected in the usual manner by venepuncture and inactivated at $56^{\circ} \mathrm{C}$. for 30 minutes, and then stored in the freezer at $-18^{\circ} \mathrm{C}$. until tested.

Gelatin-saline solution was used to prepare serial twofold dilutions of the patient's serum in $0.25 \mathrm{ml}$. volumes. To each of these dilutions $0.25 \mathrm{ml}$. volumes of standardized toxin dilution (containing 0.5 unit equivalent $/ \mathrm{ml}$.) were added and then well shaken. Following a 30-minute incubation period at room temperature, $0.5 \mathrm{ml}$. volumes of a $2 \%$ rabbit red blood cell suspension were added to all tubes which were shaken and placed in racks in a $37^{\circ} \mathrm{C}$. waterbath for 60 minutes. A red cell control and a haemolytic control were also included. After incubation the tubes were centrifuged at $6000 \mathrm{rpm}$ for one minute and read. The end-point taken was that tube which showed $50 \%$ haemolysis with a Klett $560 \mathrm{~m} \mu$ filter.

\section{Results}

The titres of staphylococcal AAH among the children without CF (Table I) show that with the

\footnotetext{
* Obtained from the National Institutes of Health, Bethesda, Maryland.

t Obtained from Burroughs Wellcome and Company.
} 
TABLE I

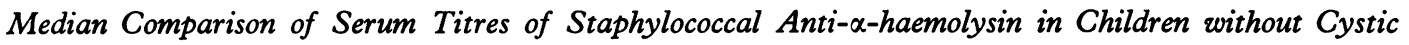
Fibrosis

\begin{tabular}{|c|c|c|c|c|c|c|c|c|}
\hline & & & & $\mathbf{N}$ & $\begin{array}{l}\text { Median } \\
\text { U./ml. }\end{array}$ & $\begin{array}{c}\text { Confidence } \\
\text { Limits of } \\
\text { Median } \\
\alpha<0.05 \text { U./ml. }\end{array}$ & $\begin{array}{c}\%<1 \cdot 0 \\
\text { U./ml. }\end{array}$ & $\begin{array}{c}\%>8 \cdot 0 \\
\text { U./ml. }\end{array}$ \\
\hline $\begin{array}{l}\text { Gastro-intestinal } \\
\text { Allergy .. } \quad . \\
\text { Rheumatic fever } \\
\text { Acute respiratory } \\
\text { Acute staphylococcal } \\
\text { Non-infectious diseas }\end{array}$ & 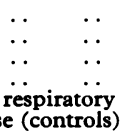 & $\begin{array}{l}\cdots \\
\cdots \\
\cdots \\
\cdots \\
\cdots\end{array}$ & $\begin{array}{l}\cdots \\
\cdots \\
\cdots \\
\cdots \\
\cdots\end{array}$ & $\begin{array}{r}70 \\
32 \\
12 \\
12 \\
9 \\
24\end{array}$ & $\begin{array}{l}1 \cdot 0 \\
1 \cdot 0 \\
1 \cdot 0 \\
1 \cdot 0 \\
1 \cdot 0 \\
1 \cdot 0\end{array}$ & $\begin{array}{l}1.0 \text { to } 1 \cdot 0 \\
1.0 \text { to } 1 \cdot 4 \\
1.0 \text { to } 1 \cdot 4 \\
1.0 \text { to } 1 \cdot 0 \\
1.0 \text { to } 49 \cdot 5 \\
1.0 \text { to } 1.0\end{array}$ & $\begin{array}{l}70 \\
53 \\
73 \\
92 \\
67 \\
92\end{array}$ & $\begin{array}{r}3 \\
0 \\
0 \\
0 \\
22 \\
4\end{array}$ \\
\hline
\end{tabular}

exception of the staphylococcal respiratory group, the AAH levels in the various groups were below 2 units $/ \mathrm{ml}$., which value is considered the upper limit of normal (Widholm, 1951; Towers and Gladstone, 1958).

Of the 138 children with cystic fibrosis, 21 were less than 6 months of age, and included both mild and severe cases. Their AAH titres were all less than 1 unit $/ \mathrm{ml}$. Because of the possible immunological incompetence of these infants, they are excluded from further analysis. In Table II the median staphylococcal AAH titres in $117 \mathrm{CF}$ patients over the age of 6 months with different degrees of pulmonary severity are higher than those of the control groups. Marginal overlap of titres existed between the mild and severe categories, and both exacerbation groups (mild and severe) had higher medians than the CF patients with mild pulmonary involvement without exacerbation.

An examination of the tracheobronchial secretions of $10 \mathrm{CF}$ patients for AAH all showed titres less than 1 unit $/ \mathrm{ml}$., including those obtained from individuals with high serum AAH levels.

A study was made of the clinical correlation with the serum AAH levels in serial blood samples collected over several years from 46 of the 117 patients with cystic fibrosis. Despite intense respiratory disease in the presence of staphylococci, $16(34 \cdot 8 \%)$ showed no response at any time.
Other immunological studies which would be of interest in this group were not carried out. In 4 cases the titres were definitely high and did not exhibit any fluctuations over a prolonged period of time. The serum AAH levels in 7 patients gradually increased with progressive disease. In 19 cases the serum titres rose during periods of respiratory exacerbation and returned to the previous baseline level at a point of subsequent clinical remission. An illustration of this varying response pattern is observed in a patient over a four-year period. This patient with severe chronic pulmonary disease whose serum AAH titre was high when first tested showed evidence of increased levels (as high as a fourfold rise in one episode) after each clinical exacerbation, which usually returned to new higher baseline levels during clinically stable periods. Then a period of remission ensued in this child with a concomitant decrease in AAH titre and a significant drop in the relative numbers of staphylococci (as seen in the sputum by smear and culture) which still later no longer produced $\alpha$-haemolysin in vitro.

Since the reason for the varying titres was obscure, the response of 3 patients with cystic fibrosis to a series of injections of staphylococcus toxoid ${ }^{\star}$ with increasing doses $(0.02 \mathrm{ml}$. intradermally to $0.5 \mathrm{ml}$. intramuscularly) given at intervals of 4-5 days over

* Staphylococcus toxoid-Vaccine Vatox, The National Drug Company.

TABLE II

Median Serum Titres of Staphylococcal Anti- $\alpha$-haemolysin in 117 Patients with Cystic Fibrosis of Different Degrees of Pulmonary Severity

\begin{tabular}{|c|c|c|c|c|c|c|c|c|}
\hline & & & & $\mathrm{N}$ & $\begin{array}{c}\text { Median } \\
\text { U./ml. }\end{array}$ & $\begin{array}{c}\text { Confidence } \\
\text { Limits of } \\
\text { Median } \\
\alpha<0.05 \\
\text { U./ml. }\end{array}$ & $\begin{array}{c}\%<1 \cdot 0 \\
\text { U./ml. }\end{array}$ & $\begin{array}{l}\%>8 \cdot 0 \\
\text { U./ml. }\end{array}$ \\
\hline $\begin{array}{l}\text { Mild } \ldots \text {. } \ldots \\
\text { Mild with exacerbation } \\
\text { Severe . } \\
\text { Severe with exacerbation }\end{array}$ & $\begin{array}{l}\cdots \\
\cdots \\
\cdots\end{array}$ & $\begin{array}{l}\cdots \\
\cdots \\
\cdots\end{array}$ & $\begin{array}{l}. . \\
\cdots \\
\cdots\end{array}$ & $\begin{array}{l}53 \\
11 \\
29 \\
24\end{array}$ & $\begin{array}{l}1 \cdot 7 \\
5 \cdot 9 \\
3 \cdot 4 \\
5 \cdot 8\end{array}$ & $\begin{array}{l}1 \cdot 3 \text { to } 2 \cdot 6 \\
3 \cdot 4 \text { to } 6 \cdot 1 \\
2 \cdot 3 \text { to } 5 \cdot 9 \\
3 \cdot 0 \text { to } 7 \cdot 5\end{array}$ & $\begin{array}{l}32 \\
0 \\
17 \\
0 \cdot 8\end{array}$ & $\begin{array}{r}0 \\
0 \\
14 \\
25\end{array}$ \\
\hline
\end{tabular}


a 4-week period was assessed. In an infant under 6 months, such immunization procedure yielded no detectable change from the initial value of $<1 \mathrm{unit} /$ $\mathrm{ml}$. In a 1-year-old child, a response from $<1$ unit $/ \mathrm{ml}$. to 2.6 units $/ \mathrm{ml}$. was observed. In a $15-$ year-old patient with an initially high titre of $12 \cdot 9$, the level more than tripled $(47 \cdot 6$ units $/ \mathrm{ml}$ ) with this stimulus. None of these patients during staphylococcal toxoid immunization had any clinical signs of respiratory exacerbations. The conclusion that the increase of titre in these patients was a specific response to staphylococcal toxin was strengthened by the lack of a rise of both streptococcal antibodies and diphtheria antitoxin following the staphylococcal toxoid injections.

\section{Discussion}

The observations recorded in this paper indicate that the children with cystic fibrosis exhibit an immune response to at least one antigenic product (the $\alpha$-haemolysin) of the staphylococci, to which they are chronically hosts, with titres of a significant degree as a group in contrast to the control groups. This observation is in contrast with many references (Blair and Hallman, 1935; Widholm, 1951; Lack, 1957; Quie and Wannamaker, 1964) to a lack of serological response to staphylococcal $\alpha$-haemolysin in other chronic staphylococcal infections, such as osteomyelitis. Even when AAH titres do occur in osteomyelitis, often they do not correlate with the course of the disease (Elek, 1959).

An important and not unexpected observation was the failure to measure any $\mathrm{AAH}$ response in the infants below 6 months of age (Chlouverakis, Griffiths, and Swift, 1963). It is here that a moderate level of mortality still exists. The higher incidence of death in this infant group at a period of immunological incompetence raises the question of utilization of high staphylococcal antibody $\gamma$-globulin as a passive therapeutic measure.

The reason for very low levels of $\alpha$-antitoxin in the bronchial secretions tested is also open to speculation. These findings are analogous with those low levels observed in milk serum of some cows with high serum antistaphylolysin titres (Thörne, 1958).

The significant point of this investigation may be that in a longitudinal study of a given patient the fluctuations in AAH titres provide additional information in the evaluation of episodes of respiratory infection.

\section{Summary}

The staphylococcal anti- $\alpha$-haemolysin (AAH) titres of 138 patients with cystic fibrosis (CF) indicate there is an immunological response to their persistent bacterial flora.

The CF patients over 6 months of age had median serum titres of AAH above those of control children. The 21 infants under 6 months of age all showed titres less than 1 unit $/ \mathrm{ml}$.

Very low levels of AAH were found in the bronchial secretions tested even when the concomitant serum titres were high.

The fluctuations of serial serum AAH in many CF patients paralleled the changing clinical state; in others there was no correlation.

The authors wish to thank Dr. Le Roy Braddock for statistical help in the analysis of the data.

\section{REFERENCES}

Blair, J. E., and Hallman, F. A. (1935). Staphylococcal antihemolysin in osteomyelitis and other staphylococcal infections. Proc. Soc. exp. Biol. (N.Y.), 33, 382.

Chlouverakis, K., Griffiths, L. L., and Swift, P. N. (1963). The relation of the staphylococcal $\alpha$-antihaemolysin titre to infection in the newborn. Arch. Dis. Childh., 38, 500.

Elek, S. D. (1959). Staphylococcus Pyogenes and Its Relation to Disease. Livingstone, Edinburgh.

Gladstone, G. P., Mudd, S., Hochstein, H. D., and Lenhart, N. A. (1962). The assay of anti-staphylococcal leucocidal components (F and S) in human serum. Brit. F. exp. Path., 43, 295.

Halbert, S. P., di Sant' Agnese, P. A., and Kotek, F. R. (1960). Staphylococcal antibodies in cystic fibrosis of the pancreas. Pediatrics, 26, 792.

Huang, N. N., Van Loon, E. L., and Sheng, K. T. (1961). The flora of the respiratory tract of patients with cystic fibrosis of the pancreas. F. Pediat., 59, 512.

Iacocca, V. F., Sibinga, M. S., and Barbero, G. J. (1963). Respiratory tract bacteriology in cystic fibrosis. Amer. F. Dis. Child., $106,315$.

Lack, C. H. (1957). Staphylococcal antibody in osteomyelitis and suppurative arthritis. Proc. Roy. soc. Med., 50, 625.

Mudd, S., Gladstone, G. P., Lenhart, N. A., and Hochstein, H. D. (1962). Titrations of antibodies against $\alpha$-haemolysin and the components of staphylococcal leucocidin in human subjects following immunization. Brit. f. exp. Path., 43, 313.

Quie, P. G., and Wannamaker, L. W. (1964). Serum antibodies in staphylococcal disease. Pediatrics, 33, 63.

Thörne, H. (1958). The antistaphylolysin titre in cattle with special reference to chronic staphylococcal mastitis. Nord. Vet.-Med., 10, 63.

Towers, A. G., and Gladstone, G. P. (1958). Two serological tests for staphylococcal infection. Lancet, 2, 1192.

Widholm, O. (1951). Antistaphylolysin titres (Asta) in normal and pathological sera with especial reference to gynecological infections. Ann. Med. exp. Fenn., 29, 150. 